\title{
Water content of stingless bee honeys (Apidae, Meliponini): interspecific variation and comparison with honey of Apis mellifera*
}

\author{
Lubertus BIJLSMA ${ }^{\mathrm{a}}$, Luc L.M. de BRUIJN ${ }^{\mathrm{b}}$, Edwin P. MARTENS ${ }^{\mathrm{c}}$, \\ Marinus J. SOMMEIJER ${ }^{\mathrm{b}}$ \\ a Analytical Chemistry, Experimental Sciences Dept., University Jaume I, Campus Rui Sec, \\ 12071 Castellón, Spain \\ b Bee Research Department, Utrecht University, PO Box 80.086, 3508 TB Utrecht, The Netherlands \\ ${ }^{\mathrm{c}}$ Centre of Biostatistics, Utrecht University, Padualaan 14, $3584 \mathrm{CH}$ Utrecht, The Netherlands
}

Received 25 February 2005 - Revised 27 June 2005 - Accepted 19 December 2005

\begin{abstract}
Honey samples were taken on both islands of the country of Trinidad and Tobago, from colonies of Melipona favosa, Melipona trinitatis, Plebeia tobagoensis, Trigona nigra and Apis mellifera. The Moisture Content (MC) of honeys of the various bee species differed significantly. The honey of the smaller species, $P$. tobagoensis and T. nigra, had higher MC values than that of the larger Melipona. The highest MC value was found in honey from P. tobagoensis (42.0\%). The other MC values were $36.2 \%$ for T. nigra, $31.2 \%$ for $M$. favosa and $32.2 \%$ for M. trinitatis. The lowest MC was found in honey of A. mellifera $(20.2 \%)$. There was little variation between colonies of the same species at the same site, but honey of $M$. favosa from Trinidad had a higher MC (35.1\%) than that from Tobago (30.2\%). The finding that the MC of honeys of stingless bee species varies according to the species and to the area where it is produced, complicates the establishment of a quality standard for these honeys.
\end{abstract}

honey composition / Melipona / Trigona / Plebeia

\section{INTRODUCTION}

Social organisation and colony living evolved in several taxa of the family Apidae but large colonies that store considerable amounts of food occur only in the stingless bees (Meliponini) and in the honeybees (Apini). The Meliponini (about 400 species) are exclusively tropical whereas the Apini contain tropical as well as temperate species. Perennial colonies require a steady flow of food, and food storage makes it possible to cope with short interruptions in food availability.

Corresponding author: L. Bijlsma, rbijlsma@yahoo.com

Present address: Havenstraat 131, 3861 VW Nijkerk, The Netherlands.

* Manuscript editor: Marla Spivak
The composition of stingless bee honeys appears to differ markedly from that of Apis honey. These honeys are often not sweet. Nogueira-Neto (1970) and Cortopassi and Gelli (1991) reported that some stingless bee honeys tasted acidic. A high water content of stingless bee honey has been reported by various authors (Nogueira-Neto, 1970; Cortopassi and Gelli, 1991; Vit et al., 1994, 1998; De Bruijn and Sommeijer, 1997; Torres et al., 2004). In a survey of 27 species, Roubik (1983) found an average moisture content (MC) of $31 \%$. The diversity of the stingless bees in body size and colony population is reflected in the volume of their honey production. Certain species can produce considerable amounts $\left(5-10 \mathrm{dm}^{3}\right)$ of honey per year, while other species only produce a few hundred $\mathrm{cm}^{3}$. 
Beekeeping with stingless bees is a wellknown and wide-spread tradition in tropical countries. This is particularly the case in the neotropics. The honey from stingless bees is highly appreciated locally and traditionally considered to be more powerful as a natural medicine for treating common diseases than honey of the introduced and more productive honey bee (Apis mellifera). Only few studies have been conducted to analyse the composition of stingless bee honey. Recently, based on data from earlier papers, Vit et al. (2004) proposed some recommendations for quality standards for stingless bee honeys compared with official standards for A. mellifera honey.

De Bruijn and Sommeijer (1997) presented their first results on the composition, properties and antibiotic activity of honeys of different species of Melipona and compared them to those of Apis. They found that honey of $M$. favosa and M. trinitatis contained on average $23.5 \%$ moisture $(\mathrm{N}=28)$. The Melipona honeys were further characterized by a significantly lower $\mathrm{pH}$ and by having more free acids. In addition, these honeys did not contain diastase, and contained a different microflora, characterized by the (near) absence of yeasts and a dominant presence of Bacillus. In a recent study, Torres et al. (2004) found that the honey of the small stingless bee, Tetragonisca angustula, had an antimicrobial effect on cultivations of bacteria but not on fungi.

The objective of this paper was to investigate the moisture content (MC) of honey produced by different sympatric species of stingless bees and to compare these honeys with the honey of A. mellifera kept in the same tropical environment. This comparison may contribute to the understanding of the difference between honeys of stingless bees and honeybees. The results may also provide a background for the medicinal value that is widely being ascribed to the different honeys of stingless bees in tropical America.

\section{MATERIALS AND METHODS}

\subsection{Bees and colonies}

Melipona favosa is a small Melipona species with a body length (worker) of 7-8 $\mathrm{mm}$. Colonies

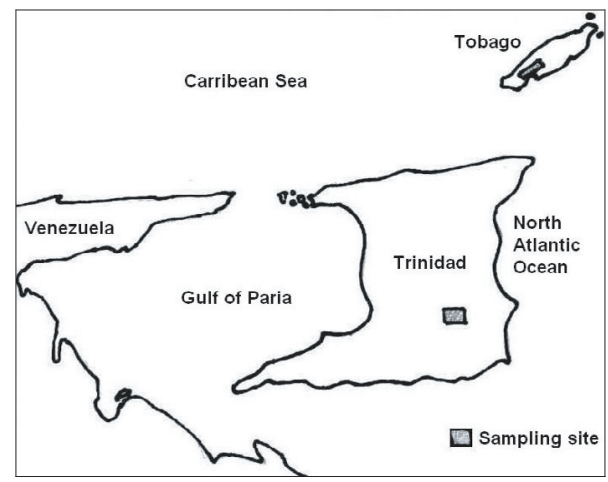

Figure 1. Map of sampling sites. Tobago (11 ${ }^{\circ} 12^{\prime} \mathrm{N}$ and $60^{\circ} 44^{\prime} \mathrm{W}, 0-100 \mathrm{~m}$ above sea level), Trinidad ( $10^{\circ} 18^{\prime} \mathrm{N}$ and $61^{\circ} 10^{\prime} \mathrm{W}, 0-100 \mathrm{~m}$ above sea level).

are generally small with about $200-500$ bees in Trinidad and Tobago. (Thriving colonies of this species in the Surinam mangrove area were observed to contain as many as 800 bees (observation Sommeijer)).

Melipona trinitatis is a larger species of this genus, with a body length of $10-11 \mathrm{~mm}$. Colonies can contain up to 1000-2000 individuals and the nests can be several times larger than those of $M$. favosa. M. trinitatis only occurs in Trinidad, W.I.

Plebeia tobagoensis is a small stingless bee with a body size of about $4 \mathrm{~mm}$, and a colony population ranging from $40-1500$ bees. This species is described from Tobago, but may have a wider distribution.

Trigona nigra is a widely distributed species with a slender body of about 5-6 $\mathrm{mm}$. The colony population in Trinidad and Tobago is 500 1200 bees.

The general biology of stingless bees is reviewed in e.g. Michener (1974), Sakagami (1982), Roubik (1989) and Sommeijer and de Bruijn (1994).

\subsection{Honey samples}

Samples were taken during two field trips to Trinidad and Tobago (Fig. 1), in August 1998 and in October 2002. Our sampling site in Trinidad was in the south eastern humid forested area of the island, near Rio Claro and the colonies in Tobago were all situated in the southern part of this island.

A total of 717 honey samples were taken from open and closed storage pots in colonies, managed by beekeepers, of $M$. favosa, $M$. trinitatis, $P$. tobagoensis, T. nigra and from sealed honey storage in 
A. mellifera. In August 1998, honeys of M. favosa ( $\mathrm{N}=408$ from 18 different colonies in Tobago) were collected. In October 2002 honeys were collected from $M$. favosa $(\mathrm{N}=86$ from two colonies in Tobago, and $\mathrm{N}=22$ from one colony in Trinidad), M. trinitatis ( $\mathrm{N}=62$ from two colonies in Trinidad), P. tobagoensis ( $\mathrm{N}=71$ from two colonies in Tobago), T. nigra ( $\mathrm{N}=57$ from two colonies in Tobago), A. mellifera ( $\mathrm{N}=2$ from two colonies in Trinidad, and $\mathrm{N}=9$ from nine colonies in Tobago).

\subsection{Measuring honey storage}

In 2002, the total number of honey pots per colony was counted in two average-sized colonies of each species except $M$. trinitatis. The volume of open and closed pots was measured by sampling from at least 10 pots per hive. Honey was extracted from the pots by the use of a syringe and the volume of the individual pots was measured in a small, calibrated cylinder. The sum of these measurements was averaged. Based on these results, the total volume of honey per hive could be estimated. Only in the case of M. trinitatis in Trinidad, where we could not use small calibrated cylinders, the pot content was estimated by collecting honey from pots in a part of the hive, in one big calibrated cylinder and dividing the volume by the estimated number of honey pots.

\subsection{Measure of moisture content}

Moisture content (MC) of the samples was measured directly in the field using a handheld refractometer (Atago). MC is expressed as percentage (g moisture per $100 \mathrm{~g}$ fresh weight). Values obtained for the determination of moisture by refractometry are not absolutely correct (Bogdanov et al., 2000). However, it is a very simple and reproducible method, with an acceptable error. For the MC measurements, all closed honey pots of a colony were opened at the top and samples were taken by the use of Pasteur pipettes. A separate pipette was used for each pot and $\mathrm{MC}$ in all samples from one colony were measured directly after collecting. A comparison of the MC of honeys from closed pots with honeys from open pots could only be made for samples taken in August 1998, because of low numbers of open pots in October 2002.

\subsection{Statistical analysis}

We performed ANOVA analyses with a hierarchical model (samples nested within colonies and colonies nested within species). Since the design was unbalanced, Satterthwaite's correction was used (Satterthwaite, 1946; Zar, 1999). Arcsin transformation was used, but these results did not differ from the results done on proportions. For each island, we did a nested ANOVA followed by Tukey HSD for multiple comparison of means on the MC of honeys from closed pots of different bee species in 2002. A comparison of closed honey pots of M. favosa and A. mellifera was made between the two islands in 2002 (intraspecific difference), and between the two years (1998 and 2002) on the island of Tobago.

\section{RESULTS AND DISCUSSION}

\subsection{Honey storage per hive}

The average total number of honey pots, volume of honey per pot, and total amount of honey are shown in Table I. In addition to the honey pots, the number of pollen pots are also shown in this table.

\subsection{Interspecific differences in moisture content of honey}

The average MC values are plotted in Figure 2. The highest mean value for $\mathrm{MC}$ in closed pots taken in October 2002 was found in P. tobagoensis $42.0 \%(\mathrm{SD} 4.0 ; \mathrm{N}=71$ ) and the lowest mean value was found for $A$. mellifera on Tobago 20.0\% (SD 1.0; $\mathrm{N}=9$ ).

Nested ANOVA, on closed pots of different stingless bee species on the island of Tobago in 2002, revealed significant differences $($ F-value $=69.6 ; \mathrm{df}=3,5.68 ; P<0.001)$ and Tukey's HSD showed that all pairwise comparisons, between the water content of honeys from different species, were significant $(P<$ 0.001).

Nested ANOVA, on closed pots of $M$. favosa and $M$. trinitatis on the island of Trinidad in 2002, revealed no significant differences $($ F-value $=3.5 ;$ df $=2,1.05$; $P=0.343$ ). 
Table I. Food storage per hive. Average number of pots for honey (open and closed) and pots for pollen for two colonies and average honey volume per pot (at least 10 pots taken from each of the two hives).

\begin{tabular}{lllllll}
\hline Bee species & $\begin{array}{l}\text { closed honey } \\
\text { pots/hive }\end{array}$ & $\begin{array}{l}\text { open honey } \\
\text { pots/hive }\end{array}$ & $\begin{array}{l}\text { pollen } \\
\text { pots/hive }\end{array}$ & $\begin{array}{l}\text { Amount of } \\
\text { honey/pot in } \\
\mathrm{mL}(\mathrm{N})\end{array}$ & $\begin{array}{l}\text { SD } \\
\text { Total amount } \\
\text { of honey/ } \\
\text { hive in } \mathrm{mL}\end{array}$ \\
\hline M. favosa (1998) & 25 & 3 & 8 & $6.2(39)$ & 1.6 & 174 \\
M. favosa (2002) & 32 & 1 & 5 & $6.6(37)$ & 2.3 & 218 \\
P. tobagoensis & 125 & 0 & 43 & $0.8(22)$ & 0.5 & 100 \\
T. nigra & 62 & 2 & 15 & $1.2(23)$ & 1.1 & 77 \\
M. trinitatis & 58 & 0 & 25 & 25.0 & & 1450 \\
\hline
\end{tabular}

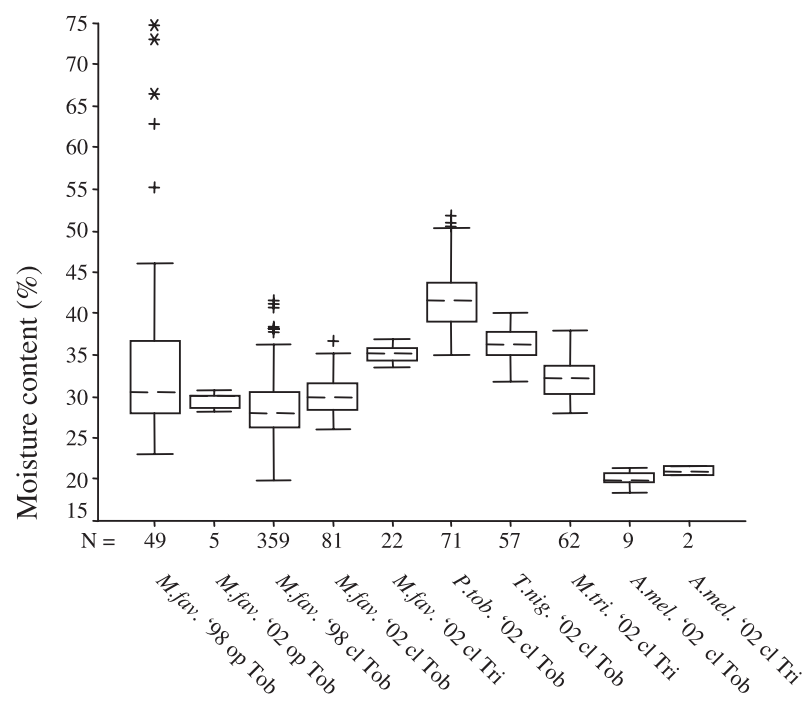

Bee species, year, open/closed pot and island

Figure 2. Boxplots of moisture content of honey for the different species. $\mathrm{N}=$ number of samples; $M . f a v .=$ Melipona favosa, M.tri. $=$ Melipona trinitatis, P.tob. $=$ Plebeia tobagoensis, T.nig. $=$ Trigona nigra, A.mel. $=$ Apis mellifera; ' 98, ' 02 = year; op = open pots, $\mathrm{cl}=$ closed pots; $\mathrm{Tob}=$ from Tobago, Tri $=$ from Trinidad.

Honeys of different species of stingless bees did have significant differences in MC, with exception of honey of M. favosa and M. trinitatis. In the study of De Bruijn and Sommeijer (1997) the honeys of $M$. trinitatis and $M$. favosa were also found to have the same MC. However in that study, the MC value was considerably lower $(23.5 \%)$ than the values in this study. This may be explained by the fact that the sampling periods in 2002 (October) and in 1998 (August) were at the end of the rainy season, whereas the honey samples from the 1997 report were collected in the dry season.
It should be noted that the honey of smallest species of our study, $P$. tobagoensis and T. nigra have much higher mean MC values than that of the larger Melipona's. The finding by Torres and collaborators of $20.5 \% \mathrm{MC}$ for the honey of the small Tetragonisca angustula, does not confirm the hypothesis that smaller species in general produce honeys with higher MC than larger stingless bees (Torres et al., 2004). For P. tobagoensis, a high MC may be related to the fact that nests of this very small species were usually located low to the ground and in rather humid conditions. 


\subsection{Intraspecific differences in moisture content of honey}

There was little variation in MC of honey measured in colonies of the same species at the same sampling site. The highest variation was found for honeys collected from $P$. tobagoensis nests. However, samples from the same stingless bee specie from different islands presented significant differences: samples from closed pots of M. favosa from Trinidad had a higher MC compared to Tobago samples (Fvalue $=52.2 ; \mathrm{df}=1,1.46 ; P=0.04)$. The average Trinidad value was $35.1 \%$ (SD 1.0; $\mathrm{N}=22$ ) and the average for Tobago was $30.2 \%$ (SD 2.2; $\mathrm{N}=81$ ). The higher $\mathrm{MC}$ for $M$. favosa honey from Trinidad may result from a higher humidity on this island. The reported average rainfall value for Trinidad is $2200 \mathrm{~mm}$ annually and for Tobago $1900 \mathrm{~mm}$ (www.rlc.fao.org/paises/h2o/trinidad.htm).

For A. mellifera there was no difference in the $\mathrm{MC}$ of honeys originating from the two islands $(\mathrm{F}$-value $=1.1 ; \mathrm{df}=1,3.74 ; P=0.353)$.

\subsection{Comparing the moisture content of honey from two years}

Honey of closed pots of M. favosa, on the island of Tobago, of the year 1998 and 2002 were compared to determine de year-to-year variability. Nested ANOVA revealed no significant differences $(\mathrm{F}$-value $=0.46 ; \mathrm{df}=1$, 17.57; $P=0.506)$.

\subsection{Comparing the moisture content of honey in open and closed pots}

For the large series of pots sampled in colonies of M. favosa in August 1998, the MC of honey in open pots was in general much higher than in closed pots. The average MC value for closed pots was $28.4 \%$ (SD $3.4 ; \mathrm{N}=359$ ) and for open pots $35.0 \%$ (SD $12.1 ; \mathrm{N}=49$ ). The samples from open pots varied considerably since some of these had very high $\mathrm{MC}$ values. Maximum MC value was $74.7 \%$ (Fig. 2). Seasonal weather conditions as well as the typical behaviour of bees in ripening and storing honey may explain the large standard deviation in MC in open pots. During a nectar flow, collected food is discharged in open pots by foragers or by receiving nest bees (De Bruijn et al., 1989). This nectar is subsequently further dehydrated which leads to lower MC. It is therefore expected that open pots will usually have higher MC's than closed pots. However, open pots also may include pots that were opened again for use after storage. In a period of low nectar flow, open honey pots will then contain honey of lower $\mathrm{MC}$ than in periods of heavy flow.

\section{CONCLUSIONS}

\subsection{Interspecific differences in moisture content of honey}

Our results indicate that there are differences in the MC of honey of the different species. First, it was confirmed that, in general, honey of stingless bees has a higher water content than honey of A. mellifera. Torres et al. (2004) suggested that this is mainly because stingless bees collect small amounts of honey and use it rather than ripening and storing it. This cannot be generally true, since some Meliponini species collect considerable amounts of honey and store it for a prolonged period of time e.g. M. trinitatis (Sommeijer and Bootsma, 1988) and M. beecheii (Van Veen and Arce, 1999).

It is important to further study the seasonal impact on MC of stingless bee honey. It is a well-known fact (and a commercial problem) that $A$. mellifera honey from the humid tropics has a considerably higher MC than honey from a dryer tropical origin.

There may also be an influence of the type of sources visited (botanical origin) and of specific ways in which the honey is transformed and stored by the bees. In future studies it will be important to include data on the environmental context of the colonies. Observational studies on honey storage could provide further explanations for the high water content in sealed pots, e.g. combined with information on longevity of these pots. 


\subsection{High water content of stingless bee honey associated with antibiotic activity}

The occurrence of watery honey in stingless bees may be related to the humid tropical environment, in which it is difficult to extract water to low concentrations from nectar. When it is difficult to produce highly dehydrated honey there is the problem of easy spoilage of the honey. Strikingly, honeys of M. favosa and of T. nigra do not spoil more readily than well dehydrated honey bee honeys: more than a year after harvesting, these honeys remained clear and of the same taste (pers. comm. de Bruijn). Possibly, in processing nectar into honey, the bees add enzymes or other substances that lead to antibiotic or preservative activity. This hypothesis would also support the claims of the medicinal activity of these honeys.

\subsection{Stingless bee honey as a variable bee product}

It is clear from these results that it is difficult to produce general quality standards for all stingless bee honey. In our study which focussed solely on the MC of these honeys, we see that in natural colonies the MC varies between 28.4\% (Tobago samples of M. favosa, August 1998) and 42.0\% (Tobago samples of P. tobagoensis, October 2002). The finding that the MC of honey of the same stingless bee species also seems to vary according to the area where it is produced, further complicates the establishment of quality standards. In the recommendations by Vit et al. (2004) it is proposed that the water content for honey of Melipona, Scaptotrigona and Trigona honey should be maximally $30 \%$. It is remarkable that nearly none of the honeys collected during our study reached such low levels.

\section{ACKNOWLEDGEMENTS}

Gijsbert Zomer and Elbert A. Hogendoorn of the Dutch National Institute of Public Health and the Environment (RIVM) gave very stimulating comments and suggestions. Ferdinand Bijlsma is thanked for his assistance during sampling. We are thankful to a number of persons in Trinidad and Tobago W.I. who provided essential assistance for our studies. Harrypersad Ramsamooj, Rio Claro, Trinidad, supplied substantial support. Gladstone Solomon, president of the Tobago Apicultural Society and many other beekeepers on the island of Tobago have contributed greatly to this work and have made the field studies possible. We wish to thank the Tobago House of Assembly (Mr. Hugh McKennah, Secretary of Agriculture) and the complete staff of the Agricultural Department at the Botanic Station. The visit of LLMdB to Trinidad and Tobago has been funded by the UyttenboogaartEliasen Stichting.

Résumé - Teneur en eau des miels d'abeilles sans aiguillon (Apidae, Meliponini) : variation interspécifique et comparaison avec le miel d'Apis mellifera. Nous avons étudié la teneur en eau (MC) du miel de diverses espèces sympatriques d'abeilles sans aiguillon et l'avons comparé à celle du miel d'Apis mellifera produit dans le même environnement tropical à Trinidad et Tobago. Sept cent dix sept échantillons de miel ont été prélevés dans des réserves operculées et non operculées dans des colonies de Melipona favosa, Melipona trinitatis, Plebeia tobagoensis, Trigona nigra et $A$. mellifera. La valeur moyenne la plus forte de MC dans les pots operculés $(42,0 \%)$ a été trouvée chez $P$. tobagoensis et la plus faible $(20,2 \%)$ chez A. mellifera. Les autres valeurs de la MC étaient de 36,2\% pour T. nigra, de $31,2 \%$ pour $M$. favosa et de $32,2 \%$ pour $M$. trinitatis. La variation entre colonies de la même espèce sur le même site d'échantillonnage a été faible, mais le miel de $M$. favosa de Trinidad avait une MC plus forte $(35,1 \%)$ que celui de Tobago (30,2\%). Pour les grandes séries provenant des colonies de $M$. favosa en août 1998, la teneur en eau du miel dans les pots non operculés était beaucoup plus forte $(35,0 \%)$ que dans les pots operculés $(28,4 \%)$. Nos résultats confirment que le miel des abeilles sans aiguillon possède une teneur en eau généralement beaucoup plus forte que celui d'A. mellifera. Le phénomène du miel aqueux chez les abeilles sans aiguillon peut être lié à l'environnement tropical humide, où il est difficile de produire un miel fortement déshydraté. Le problème de la détérioration facile du miel aqueux pourrait être surmonté si les abeilles ajoutaient des enzymes ou d'autres substances ayant une activité antibiotique, ce qui corroborerait les allégations d'activité médicinale de ces miels.

Melipona / Trigona / Plebeia / miel / teneur en eau / Meliponini 
Zusammenfassung - Wassergehalte in Honigen von Stachellosen Bienen (Apidae, Meliponini): interspezifische Variation und Vergleich mit Apis mellifera Honig. In der vorliegenden Studie untersuchten wir den Wassergehalt (WG) in Honigen verschiedener in Trinidad und Tobago sympatrisch vorkommender Stachelloser Bienen und verglichen diese mit Apis mellifera Honigen aus der gleichen Tropenregion. Aus Kolonien von Melipona favosa, Melipona trinitatis, Plebeia tobagoensis, Trigona nigra und Apis mellifera wurden insgesamt 717 Honigproben aus offenen und geschlossenen Honigvorräten entnommen.

Den höchsten WG-Mittelwert für geschlossene Honigtöpfe fanden wir bei $P$. tobagoensis. Er lag bei $42 \%$. Den niedrigsten Wert $(20,2 \%)$ fanden wir bei A. mellifera. Die anderen Arten zeigten folgende Werte: $36,2 \%$ bei $T$. nigra, $31,2 \%$ bei $M$. favosa und $32,2 \%$ bei $M$. trinitatis. Wir fanden nur geringe Variationen für diese WG-Werte in Kolonien der gleichen Art und am gleichen Standort. Lediglich M. favosa Honig aus Trinidad hatte einen höheren WG $(35,1 \%)$ als der aus Tobago $(30,2 \%)$. Bei der großen Probenserie aus M. favosa Kolonien, die im August 1998 gesammelt wurden, lag der WG für Honige aus offenen Honigtöpfen bei 35,0\% und damit etwas höher als der für geschlossene Töpfe. Unsere Ergebnisse bestätigen frühere Befunde, dass Honige von Stachellosen Bienen einen höheren Wassergehalt aufweisen als A. mellifera Honige. Das Phänomen der wasserreichen Honige Stachelloser Bienen könnte mit den feuchten tropischen Klimabedingungen zusammenhängen, die die Produktion wasserarmer Honige erschweren. Das Problem der leichten Verderblichkeit dieser wässrigen Honige können die Bienen vermutlich durch Zusatz von Enzymen oder anderer Substanzen mit antibiotischer Aktivität umgehen.

\section{Honigzusammensetzung / Melipona / Trigona / Plebeia}

\section{REFERENCES}

Bogdanov S., Martin P., Lüllman C. (2000) Honey Quality, Methods of analysis and international regulatory standards: Review of the work of the international honey commission, Swiss Bee Research Centre [online] http://www.apis.admin.ch/host/doc/pdfhoney/ honeyQualMeth.pdf (accessed on 9 May 2006).

Bruijn de L.L.M., Sommeijer M.J., Leijs R. (1989) Uptake and distribution of nectar and the storage of honey in Melipona favosa (Apidae, Meliponini), Act. Coll. Insectes Soc. 5, 39-43.

Bruijn de L.L.M., Sommeijer M.J. (1997) The composition and properties of honeys of stingless bees (Melipona), in: Sommeijer M.J., Beetsma J., Boot W.-J., Robberts E.-J., Vries de R. (Eds.), Perspectives for honey production in the tropics, NECTAR: IBRA, pp. 149-168.
Cortopassi-Laurino M., Gelli D.S. (1991) Analyse pollinique, propriétés physico-chimiques et action antibactérienne des miels d'abeilles africanisées Apis mellifera et de Méliponinés du Brésil, Apidologie 22, 61-73.

Michener C.D. (1974) The social behaviour of the bees, Harvard University Press, Cambridge, Mass.

Nogueira-Neto P. (1970) A criação de abelhas indígenas sem ferrão, Chácaras e Quintais, 365.

Roubik D.W. (1983) Nest and colony characteristics of stingless bees from Panamá (Hymenoptera: Apidea), J. Kans. Entomol. Soc. 56, 327-355.

Roubik D.W. (1989) Ecology and Natural History of Tropical Bees, Cambridge University Press, Cambridge.

Satterthwaite F.E. (1946) An approximate distribution of estimates of variance components, Biometr. Bull. 2, 110-114.

Sakagami S.F. (1982) Stingless bees, in: Hermann H.R. (Ed.), Social Insects (III), Academic Press, New York, pp. 361-423.

Sommeijer M.J., Bootsma M.C. (1988) Melipona trinitatis comme productrice de miel à l'île de Trinidad, Act. Coll. Insectes Soc. 4, 291-294.

Sommeijer M.J., Bruijn de L.L.M. (1994) Intranidal feeding, trophallaxis and sociality in stingless bees, in: Hunt J., Nalepa C. (Eds.), Nourishment and Evolution in Insect Societies, Westview Press, pp. 391-418.

Torres A., Garedew A., Schmolz E., Lamprecht I. (2004) Calorimetric investigation of the antimicrobial action and insight into the chemical properties of "angelita" honey - a product of the stingless bee Tetragonisca angustula from Columbia, Thermochim. Acta 415, 107-113.

Veen van J.W., Arce Arce H.G. (1999) Nest and colony characteristics of log-hived Melipona beecheii (Apidea: Meliponini), in: Veen van J.W., Colony reproduction in stingless bees, Utrecht, The Netherlands, pp. 18-26.

Vit P., Medina M., Enríquez M.E. (2004) Quality standards for medicinal uses of Meliponea honey in Guatamala, Mexico and Venezuela, Bee World 85, 2-5.

Vit P., Bogdanov S., Kilchenmann V. (1994) Composition of Venezuelan honeys from stingless bees (Apidae: Meliponinae) and Apis mellifera L., Apidologie 25, 278-288.

Vit P., Persano Oddo L., Marano M.L., Salas de Mejias E. (1998) Venezuelan stingless bee honeys characterised by multivariate analysis of physicochemical properties, Apidologie 29, 377-389.

Zar J.H. (1999) Biostatistical Analysis, 4th ed., Upper Saddle River, Prentice Hall, New Jersey. 